\title{
RESPIRATORY PHYSIOLOGY IN RELATION TO ANAESTHESIA*
}

Fernand Grégotre, M.D., F.C.C.P. *

Ir is common knowledge that the purpose of respiration is to furnish to the tissues the oxygen needed and to remove the carbon dioxide produced by the metabolism. It seems evident that every anaesthetist tries to respect these purposes and to fulfil these requirements. Notwithstanding the progress made in recent years, the occasional patient succumbs near the end of operation or shortly thereafter, or more often barely survives a puzzling condition of low blood pressure. At such times it is customary to say: "The blopd replacement was not sufficient," or "his heart just would not stand it," and so on.

Stand what is often not clear. We shall try here to review briefly some general data on respiratory physiology, in normal and in emphysematous patients, and to describe an acidosis of potentially fatal degree which results from accepted procedures in thoracic and general surgery. We shall then try to find a way to correct it and to prevent the complications which follow it.

The normal respiration is under the control of the respiratory centre which may be influenced directly or reflexly. The neural mechanisms responsible for rhythmic respiration can be divided into basic and accessory parts.

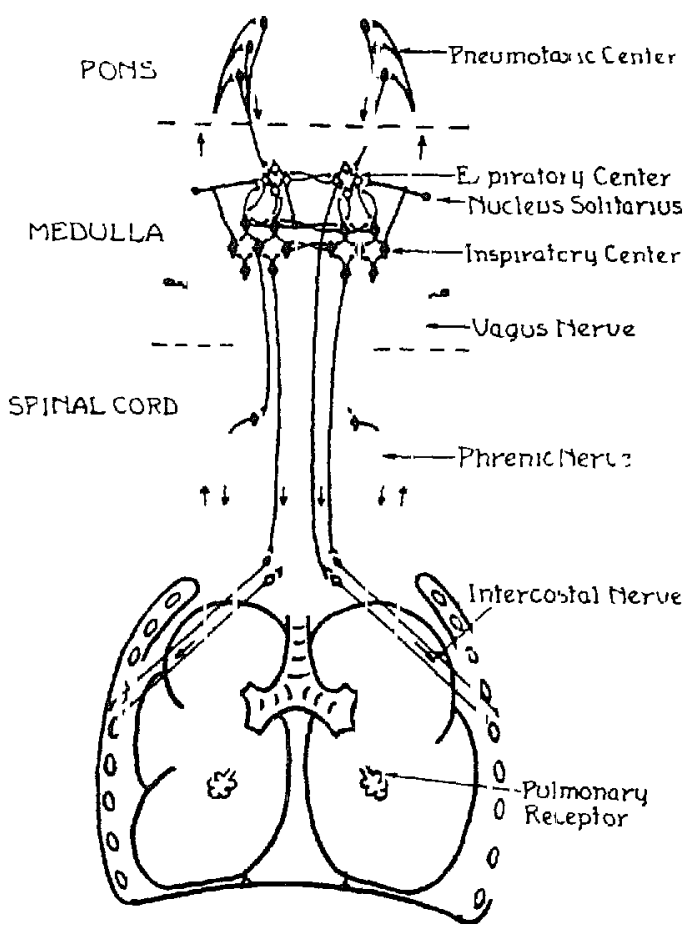

Fig 1. Diagrammatıc representation of basic neural mechanısms responsible for rhythmic respiration.

${ }^{*}$ Presented at a meeting of the Society of Anaesthesiology of Montreal, December 1.3, 1954

* Medical Director, Institut Lavoisier, 5757 Rosemount Blvd, Montreal 36 


\section{Basic Neural Mechanism (Fig. 1)}

A. Medullary respiratory centre

Inspiratory

Expiratory

B. Pneumotaxic centre in the lower pons

C. The Hering Breuer reflex or distention receptors in the lungs

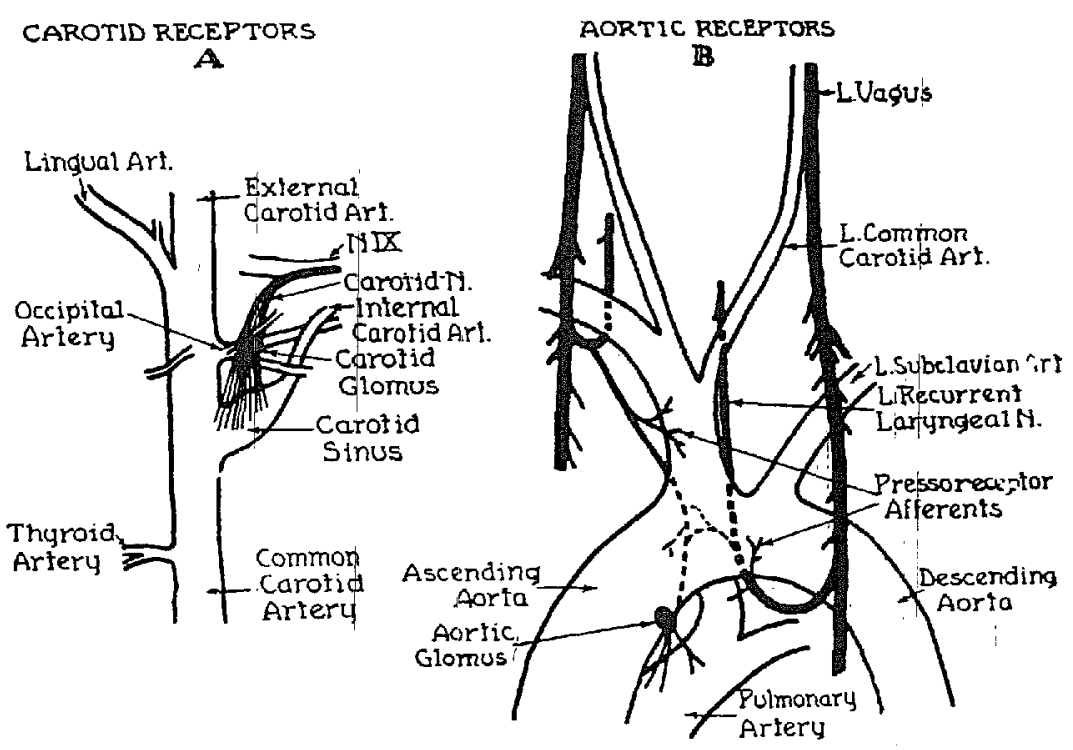

Fig. 2. Diagrammatic representation of location and neural connections of carotid and aortic chemoreceptors and pressoreceptors (dog). From Comroe, Am. J. Physiol. 127: 176 (1939); and Comroe and Schmidt, Am. J. Physiol. 121: 75 (1938).

\section{Accessory Neurat Mechanism (Fig. 2)}

Carotid and Aortic chemoreceptors

Carotid and Aortic pressoreceptors

Protective reflexes

Voluntary control

Fig. 3 shows the control of the respiration by the respiratory centre, which is influenced chemically and reflexly.

An increase of $\mathrm{CO}_{2}$ stimulates the respiration. If a normal subject is given 3 per cent $\mathrm{CO}_{2}$ to breathe, his ventilation may double, and the $\mathrm{pCO}_{2}$, normally $40 \mathrm{~mm} \mathrm{Hg}$., may increase by only 2.5 to $3 \mathrm{~mm}$. Without this hyperventilation, the $\mathrm{pCO}_{2}$ would rise to $60 \mathrm{~mm} \mathrm{Hg}$. and there would be an important acidosis.

When 9 per cent $\mathrm{CO}_{2}$ is inhaled by a normal subject, the ventilation is increased about ten-fold, and the $\mathrm{pCO}_{2}$ will go as high as 65 or $68 \mathrm{~mm} \mathrm{Hg}$. with a $\mathrm{pH}$ around 7.00.

If more than 9 per cent $\mathrm{CO}_{2}$ is inhaled, there will be some depressant effect on the respiratory centre and at higher concentrations, i.e., above $70 \mathrm{~mm} \mathrm{Hg}$. in the alveolar air, the $\mathrm{CO}_{2}$ becomes anaesthetic and may even produce lethal effects. The barbiturates, opiates, and anaesthetics are also depressors of the 


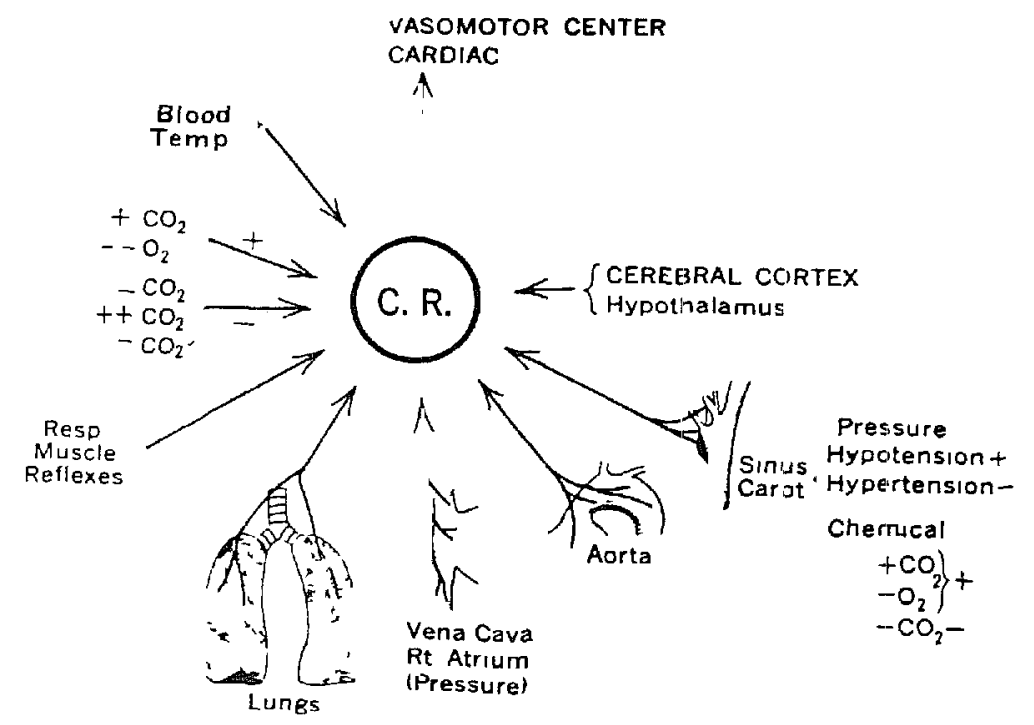

Fig. 3. Dlagram indicating the influence of $\mathrm{O}_{2}$ and $\mathrm{CO}_{2}$ in direct and reflex modifications of the respiratory centre according to conceptions of $\mathrm{D}$. Cordier and $\mathrm{C}$. Heymans (Le Centre respiratoire, Herrmann et $\mathrm{Cle}$ ).

respiratory centre. On the other hand an increase of $\mathrm{O}_{2}$ will not influence the respiratory centre of normal subjects.

A decrease of $\mathrm{CO}_{2}$ will diminish the respiration. Similarly although surprisingly, a decrease of $\mathrm{pO}_{2}$ is depressor on the respiratory centre and it is only through the chemoreceptors, i.e. the carotid and aortic glomi, that anoxia stimulates the breathing. The $\mathrm{pO}_{2}$ must drop by at least $20 \mathrm{~mm} \mathrm{Hg}$. to produce a stimulation of the chemoreceptors. An increase of $\mathrm{pCO}_{2}$ and a decrease of $\mathrm{pH}$ have also an action on the chemoreceptors, but much less than on the respiratory centre.

The pressoreceptors also play a role, but are more efficient on circulation than on respiration. We know, however, that a sudden rise in blood pressure causes apnoea and that a sharp fall produces hyperpnoea.

The Hering Breuer reflexes are very important in the reflex control of breathing. These nerves are distributed to bronchioli, alveolar ducts, and alveoli. They are essentially distention reflexes. During inspiration, they send impulses to the respiratory centre and when enough impulses are accumulated there is inhibition of the continuous discharge of the inspiratory centre and expiration starts. The greater the resistance in the lungs, due to fibrosis, congestion, or cardiac oedema, the more numerous are the impulses and the faster is the breathing.

In Fig. 4 we have an idea of what happens in a normal subject with an R.Q. of .83. The $\mathrm{pO}_{2}$ is around $100 \mathrm{~mm} \mathrm{Hg}$. and the $\mathrm{pCO}_{2} 40 \mathrm{~mm} \mathrm{Hg}$. The $\mathrm{xCO}_{2}$ closely follows the ventilation. By hyperventilation there is $\mathrm{pCO}_{2}$ fall anc $\mathrm{pO}_{2}$ increase with a high R.Q., and a high $\mathrm{pH}$ going towards alkalosis.

On the other hand, hypoventilation prevents the renewing of the air in the alveoli, and the $\mathrm{CO}_{2}$ keeps increasing, poured in from the venous blood. The $\mathrm{pCO}_{2}$ in the alveoli and in the blood gets into equilibrium, and as the $\mathrm{pCO}_{2}$ increases the $\mathrm{pH}$ of the blood becomes more and more acid.

Fig. 5 illustrates the nitrogen rinsing curves of three subjects. The subject breathes pure $\mathrm{O}_{2}$ for 7 minutes in an opened circuit, so that at the end the per- 


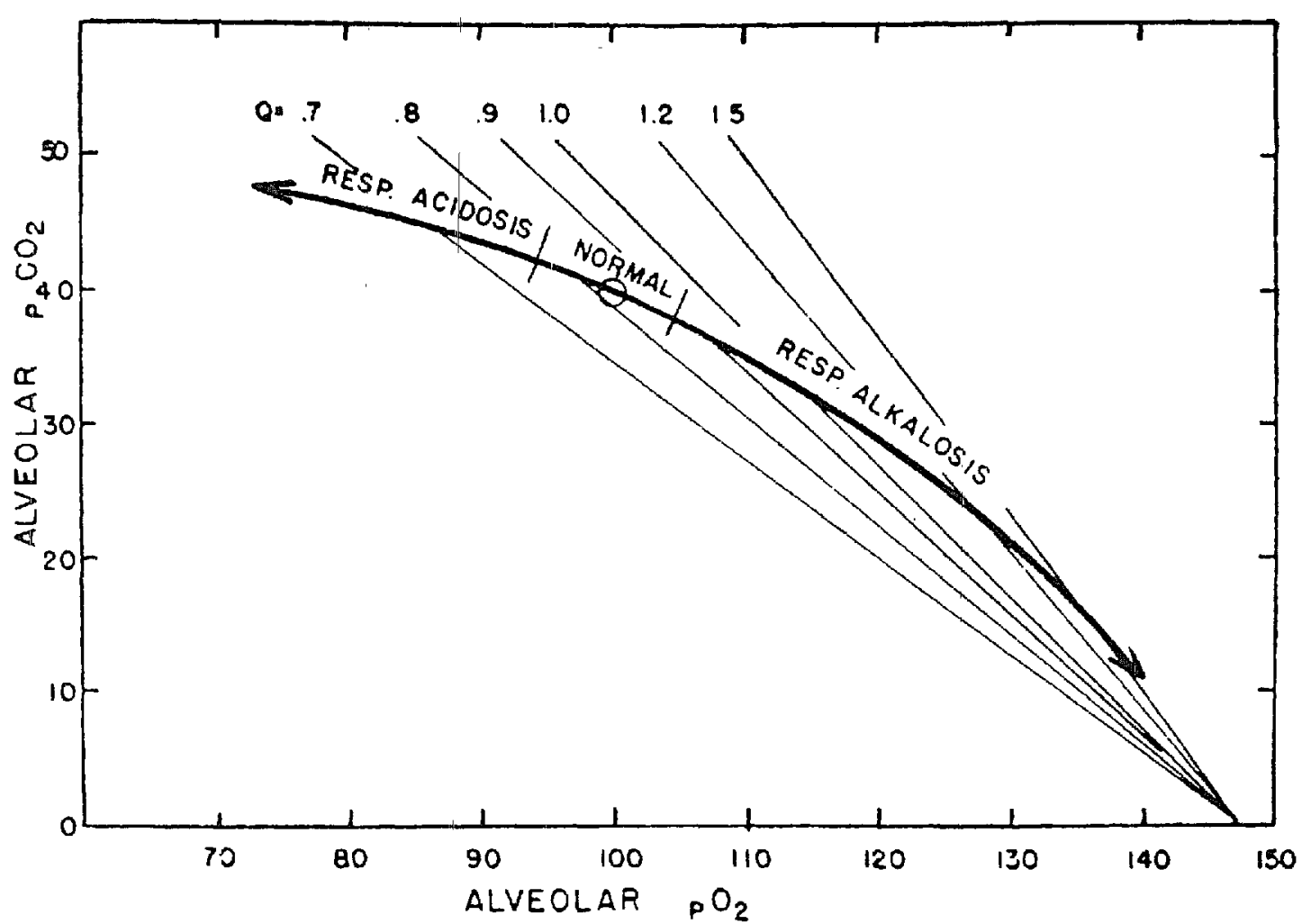

Fig. 4. Respiration in a normal subject.
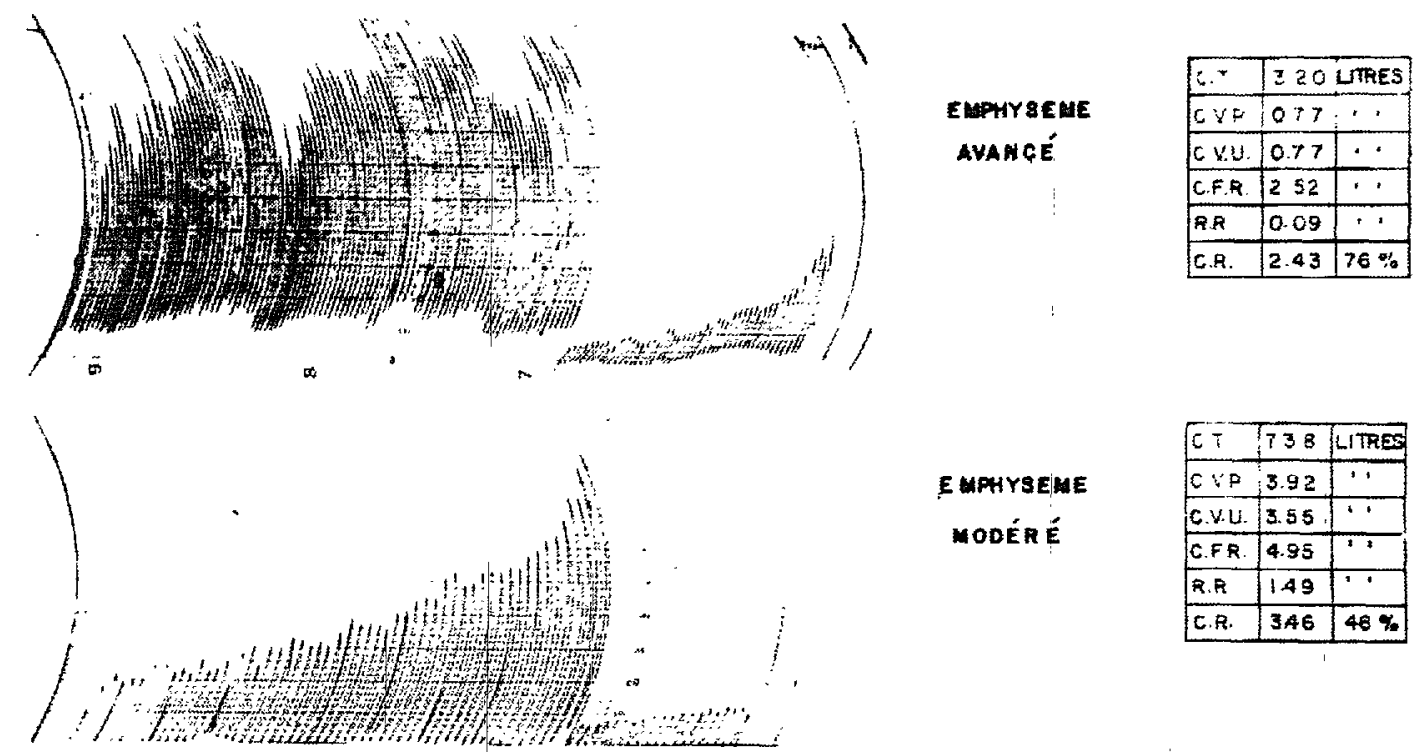

\begin{tabular}{|c|c|c|c|}
\hline \multirow{4}{*}{$\begin{array}{l}\text { E WPHYSE|ME } \\
\text { MODÉAË }\end{array}$} & ET & 738 & [LTRES \\
\hline & $0: P$ & 3.92 & " \\
\hline & c.vu & 3.55 & . \\
\hline & CFR & 4.95 & 1. \\
\hline & $\overline{R A R}$ & 149 & T \\
\hline & C.R. & 346 & $46 \%$ \\
\hline
\end{tabular}

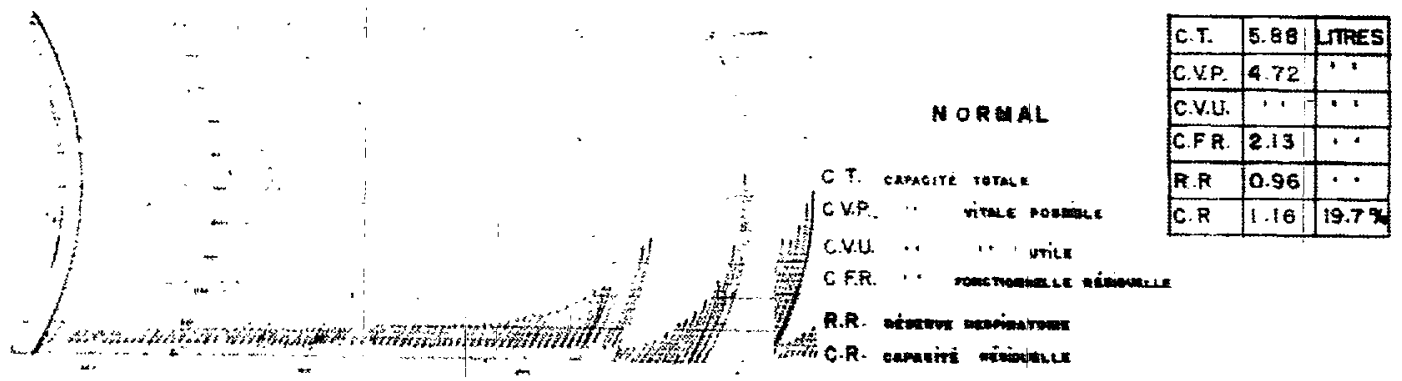

Fig. 5. Nitrogen rinsing curves of normal and emphysematous subjects. 
centage of $\mathrm{N}_{2}$ in his lungs should not be higher than 2.5 per cent. The lower curve represents a normal individual. Starting from right to left, we see the first part on the 80 per cent scale. After $1 / 2$ minutes, when the $\mathrm{N}_{2}$ in expired air is lower than 10 per cent, we shift to the 10 per cent scale. It is evident that after 3 minutes the concentration is already lower than 2.5 per cent.

The second curve belongs to a moderate case of emphysema and shows that this patient takes more time to rinse his lungs. At the end, there is still 4 per cent $\mathrm{N}_{2}$ present.

The upper curve belongs to a far advanced case of emphysema. At the end, during a forced expiration for collection of alveolar air, the concentration of $\mathrm{N}_{2}$ is more than 10 per cent.

We know that a residual air of more than 40 per cent (when this mcrease in percentage is due to an absolute increase) is the signature of emphysema. The emphysema is more pronounced when the percentage is higher. But there is not always a complete correlation between the residual air in percent and the degree of blood gas imparment. Baldwin, Cournand, and Richards suggested the following classification in an article on pulmonary insufficiency (Medicine 28: $210,1949)$.

$$
\begin{aligned}
& \text { Ist }=\text { Saturation at } 92 \% \text { or above during moderate exercise } \\
& \text { 2nd }=\text { Saturation }<92 \% \text { with a } \mathrm{pCO}_{2}<48 \mathrm{~mm} \mathrm{Hg} \\
& \text { 3rd }=\text { Saturation }<92 \% \text { with a } \mathrm{pCO}_{2}>48 \mathrm{~mm} \mathrm{Hg} . \\
& \text { 4th }=\text { Saturation }<92 \% \text { with a } \mathrm{pCO}_{2}>48 \mathrm{~mm} \mathrm{Hg} . \\
& \text { and complicated with cor pulmonale. }
\end{aligned}
$$

It has been recognized that anoxia increases the pulmonary artery pressure even in normals It is worse if there is already a dimmution of the pulmonary capillary vascular bed by emphysema or fibrosis. If a lobectomy or a pneumonectomy is performed the reduction of the pulmonary capllary bed is greater and the pulmonary hypertension is likely to develop, sometimes even at rest. The right ventricle becomes hypertrophied and dilates and decompensates. This is a short summary of the way cor pulmonale can develop after thoracic surgery.

We shall see now the results of studies performed on 19 patients before, during, and after pulmonary lobectomy or resection *

In Fig. 6 we can follow the mean ventilation before, during, and after the operation, in the recovery penod, and during the following days. We see that prior to the operation the mean total ventilation was 6.8 litres per minute and that it dropped to 4.8 litres during anaesthesia. If we assume that the dead space is $150 \mathrm{cc}$. and the respiratory rate 16 times a minute, 2.4 litres of ventilation are necessary just to wash out the dead space, and only 24 litres are really effective for alveolar ventilation.

A few patients, however, had less than 3 lites of total ventilation. This means that they did not ventılate their alveoli at all and that they succeeded in surviv-

'This work has been done in collaboration with Dr. E Bousquet and Dr L Longtn respectively Chef Surgeon and Chief Anaesthetist at St Joseph Sanatorium Hospital, arded by federal-provincial grants A complete report is now in process of publication. 


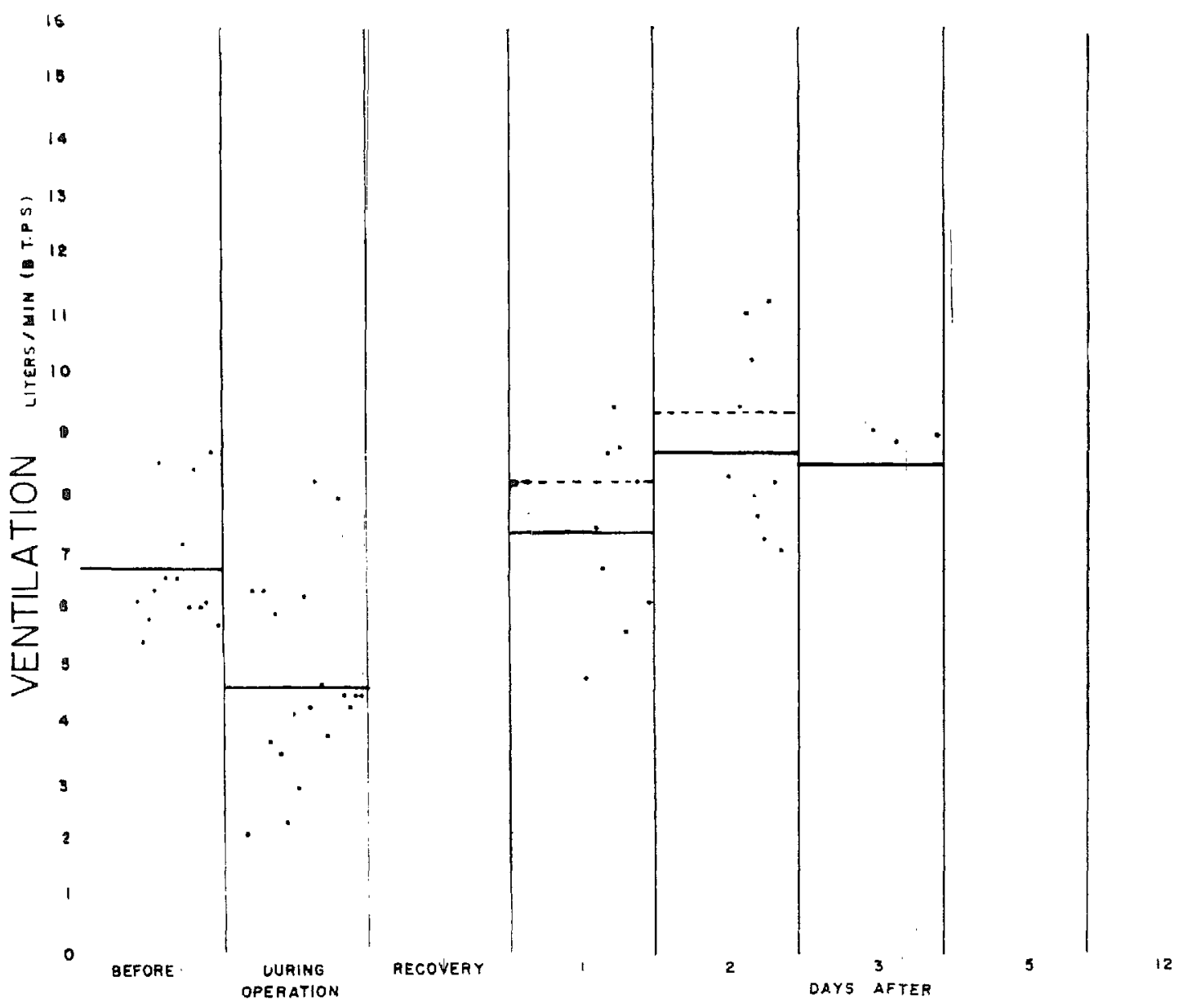

Fig. 6. Total ventilation and pulmonary resection.

ing with diffusion respiration. As the $\mathrm{CO}_{2}$ follows the ventilation closely we can suspect what influence this hypoventilation will have.

During the following days the ventilation is slightly higher than before. It is important to note that none of these patients was emphysematous and that they all received ether anaesthesia with oxygen.

Fig. 7 shows that the saturation as a mean was higher during the operation than after or before. It is evident that the first purpose of respiration, i.e. the provision of $\mathrm{O}_{2}$ to the tissues, is fulfilled.

Fig. 8 shows the $\mathrm{CO}_{2}$ content of the arterial blood. As a mean, before operation it was of $47 \mathrm{Vol}$. per cent with extremes between 42 and $50 \mathrm{Vol}$. per cent. During operation, the mean was $60.50 \mathrm{Vol}$. with extremes between 52 and $72 \mathrm{Vol}$. per cent. It is evident that a great accumulation of $\mathrm{CO}_{2}$ occurred during operation. It started to diminish in the recovery period and maintained itself slightly higher than normal in the following days.

In Fig. 9 the effect of hypoventilation is still more evident on the $\mathrm{pCO}_{2}$ determined directly, according to the method of Riley and Prommell. It was 39 $\mathrm{mm} \mathrm{Hg}$. as a mean before, with 32 to $45 \mathrm{~mm} \mathrm{Hg}$. as extremes. During operation the mean $\mathrm{pCO}_{2}$ was $90 \mathrm{~mm} \mathrm{Hg}$. with extremes from 62 td $126 \mathrm{~mm} \mathrm{Hg}$. It went 


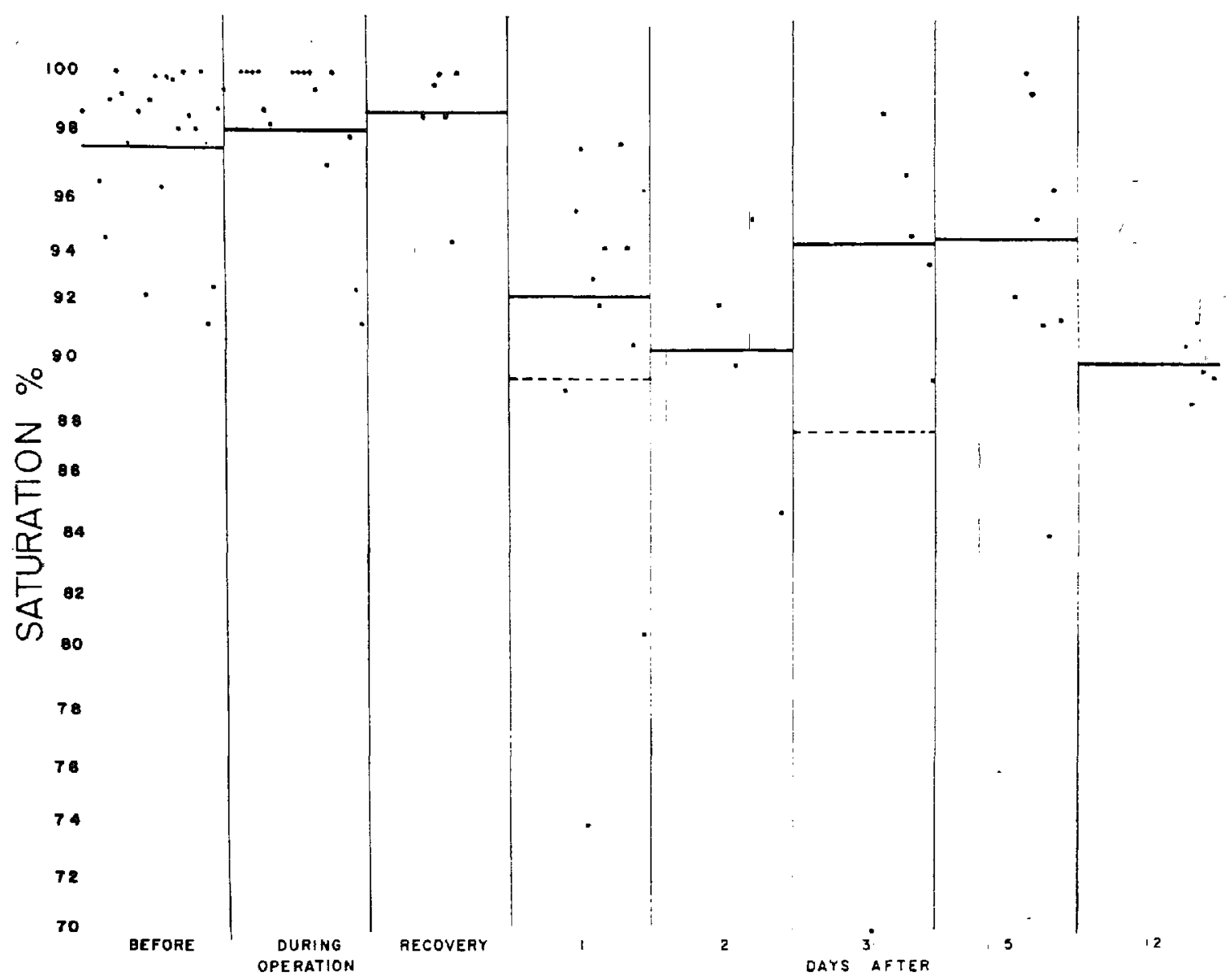

Fig. 7. Arterial blood saturation.

back to previous levels the following day, but this decrease started in the recovery period, one hour after the end of anaesthesia, when the patient had already begun to hyperventilate.

With an increase in $\mathrm{pCO}_{2}$ and in $\mathrm{CO}_{2}$ content there is respiratory acidosis (Fig. 10). PH determinations were made on a Cambridge $\mathrm{pH}$ meter and a fall in $\mathrm{pH}$ was found. It passed from 7.42 before, to 7.14 with one at 6.95 and another one at 7.00 during operation. It was found at 7.26 one hour after operation and back to previous levels two days after.

In Fig. 11 we have a summary of the effect of hypoventilation on acid base balance equilibrium during anaesthesia.

Many investigators have found the same kind of acidosis (1) (2) (3) (4) (5) (6) (7). But what are the effects of this acidosis? Goldstein and DuBois (8) have shown that a fall of blood pressure immediately follows the cessation of breathing high concentrations of $\mathrm{CO}_{2}$.

Dripps (9) has discussed the fall of blood pressure which occurs when the subject is taken off cyclopropane. He reported that under this agent the $\mathrm{pCO}_{2}$ rises to great heights; a considerable fall of blood pressure sometimes occurs when the cyclopropane is terminated. "The higher the tensions of the $\mathrm{CO}_{2}$ in the arterial blood, the greater is the likelihood of a postanesthetic decrease in blood pressure." 


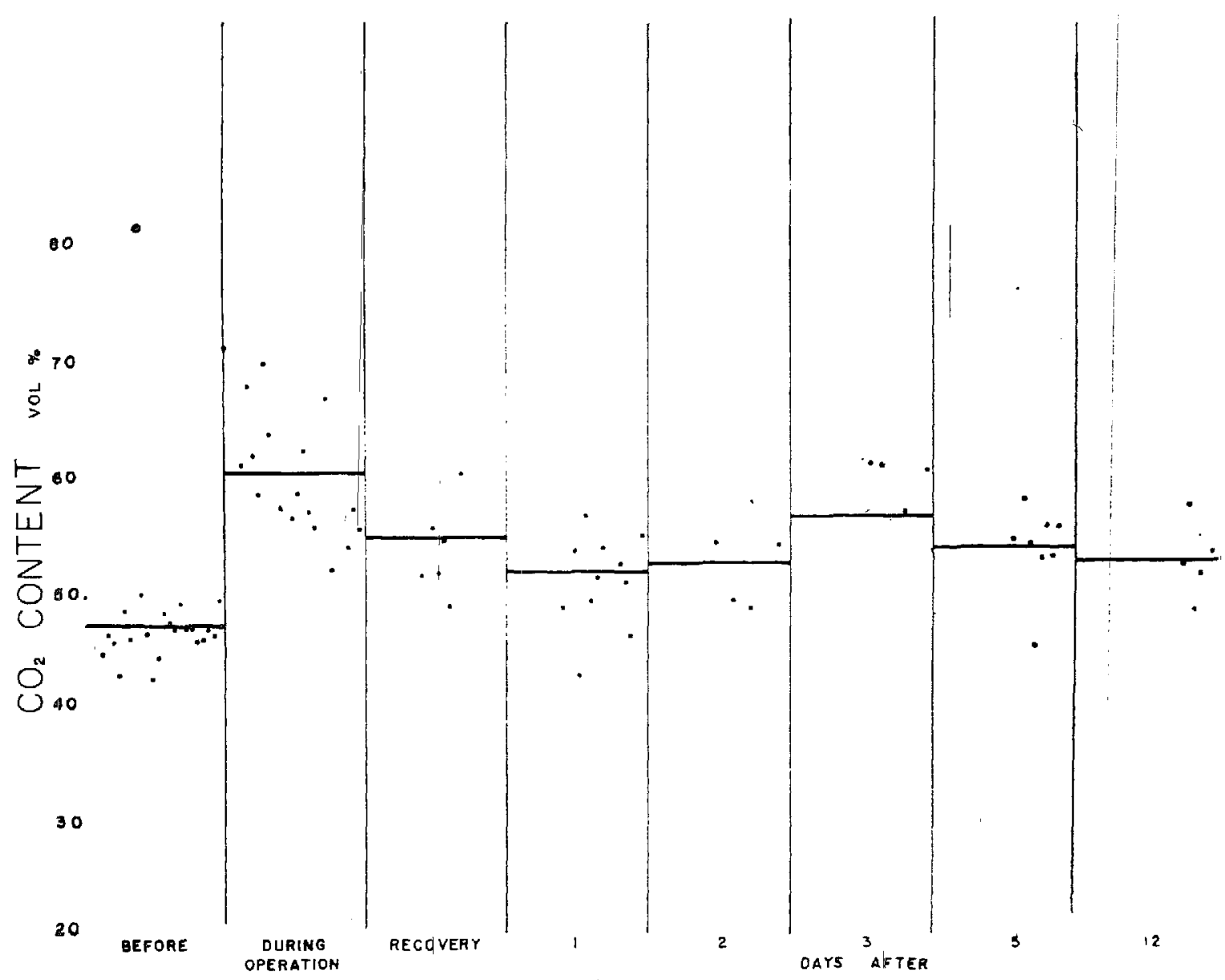

Fig. 8. $\mathrm{CO}_{2}$ content of arterial blood.

Beecher and Murphy (1) said: "When the $\mathrm{pH}$ rises and the $\mathrm{pCO}_{2}$ falls, its stimulant action is withdrawn and the blood pressure falls. As pointed out previously, there is reason to believe that this is a true cause and effect relationship."

Dr. Sealy and collaborators (6) in their paper entitled "Studies on Cardiac Arrest: The Relationship of Hypercapnea to Ventricular Fibrillation," state: "Sudden cardiac arrest constitutes one of the chief causes of death during surgery. If hypoxia, overdosage of drugs or peripheral vasometer collapse may be the known precipitating factors in some instances, the majority of cases have to be classified as due to undetermined causes."

Since several observers such as Campbell (10), Mayer and associates (2), Young and associates (11), Miller, Brown et al. (3) had already suggested that hypercapnia may be one of the responsible factors in this group, Sealy, Young and Harris (6) performed a group of experiments in their laboratory on dogs exposed to 30 and 40 per cent $\mathrm{CO}_{2}$. They stimulated the intact right vagus nerve until "vagal escape occurred." It was noted that the duration of the asystole was increased and varied directly with the degree of hypercapnia.

The dog's tolerance to severe respiratory acidosis was notable. In three instances out of nine, however, ventricular fibrillation was noted, when after a 


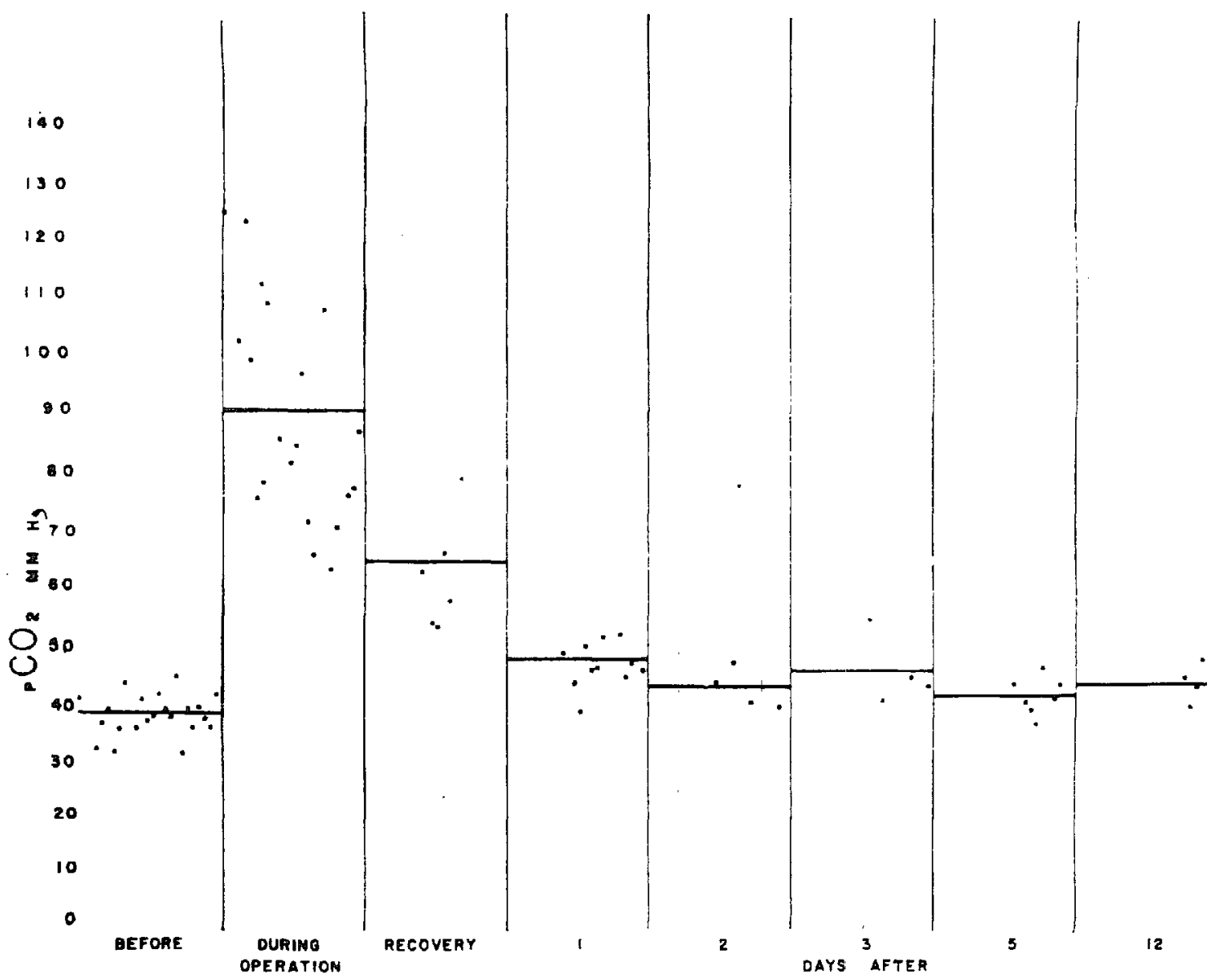

Fig. 9. Arterial blood $\mathrm{pCO}_{2}$.

long period of hypercapnia the dog was allowed to breathe room air. Significant alterations in the electrocardiogram always occurred before ventricular fibrillation. These included alterations in $T$ waves, increase in the intraventricular conduction time, ventricular extrasystoles and A-V dissociation.

Because of the similarity of the electrocardiographic changes of hyperkalemid with those in the post-hypercapneic period, the same workers performed another group of experiments using rats. The plasma potassium increased in proportion to the length of the hypercapneic period. The records of patients who developed cardiac arrest were then studied. Out of 36 cases, 24 had cardiac arrest from unexplained causes. It was considered possible that hypercapnia could have occurred in ten cases of abdominal surgery and 11 cases of thoracic surgery in the middle portion of the operation.

Brown and Miller (12) in 1952 were the first to show the exact significance of ventricular fibrillation in the immediate post-hypercapneic period in dogs. The rise in potassium levels after cessation of hypercapnia was also noted and may be due to a sudden release of adrenaline.

The hurried administration of large quantities of blood to a patient in whom ventilation and renal excretion are impaired would seem to offer a good opportunity for the occurrence of toxic levels of plasma potassium. The low $\mathrm{pH}$ of the transfused blood is possibly an adjuvent to the acidosis. 


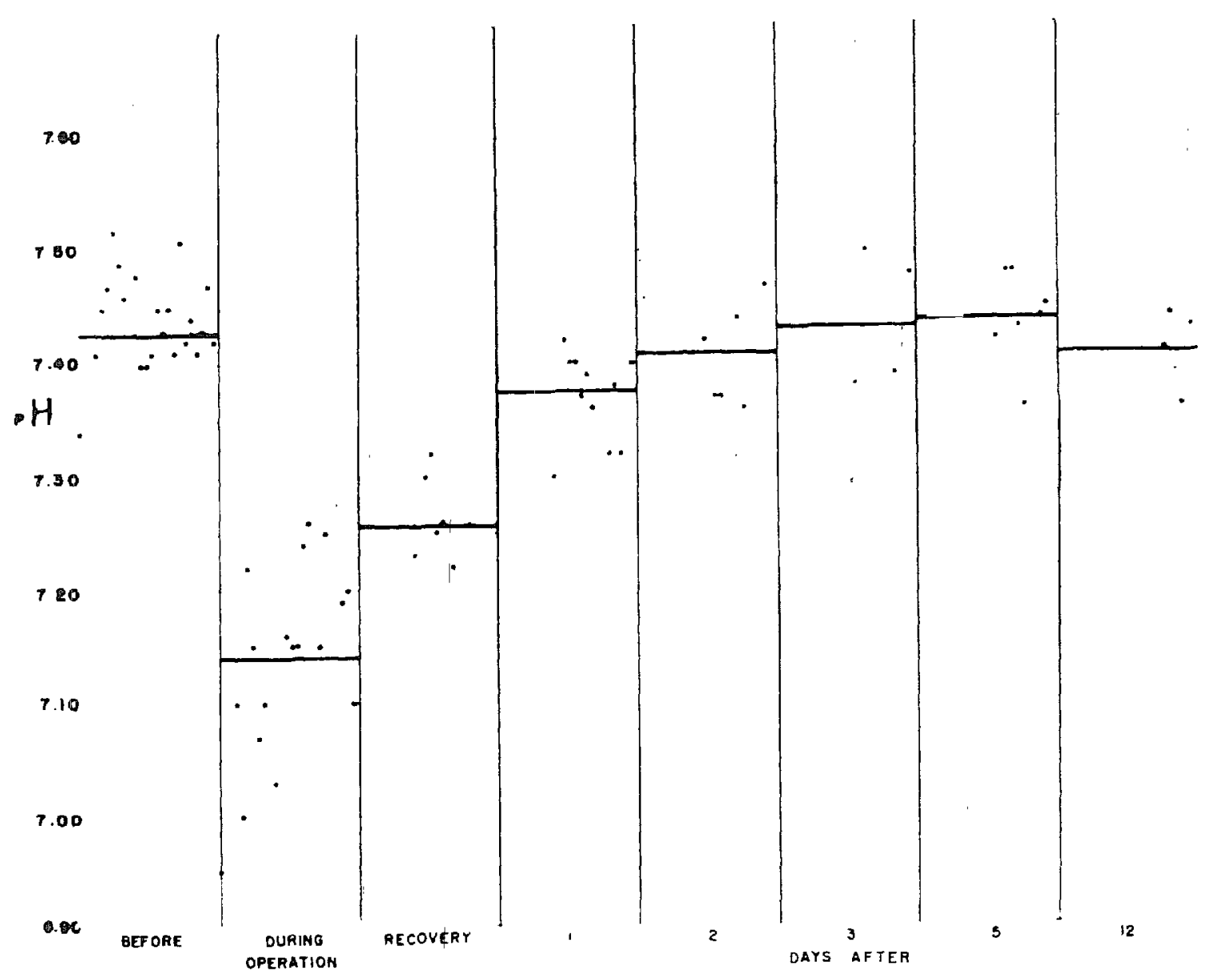

Fig. 10. Arterial blood $\mathrm{pH}$.

There are drugs such as ether which significantly decrease the blood levels of potassium. It is a plausible assumption that this agent may actually protect the heart by reducing the levels of the plasma potassium. The most important measure of prevention of respiratory acidosis is an adequate ventilation during anaesthesia.

Donald Proctor in an article on respiration and anaesthesia in Surgeon, September, 1953, stated: "It is remarkable that in this age of exact measurement the anesthetist is generally forced to estimate the adequacy of his patient's ventilation by observing or feeling the excursions of a rubber bag which, when full, holds 5 litres of gas. Even the most skilled and experienced person cannot hope to estimate such excursions accurately. As a result, most of us have relied on our ability to err on the side of overventilation. Even a superficial perusal of recent literature suffices to demonstrate how frequently the error occurs on the other side."

Our results are in full agreement with this. It seems that adequate ventilation during operation and a gradual return to room air after anaesthesia to prevent a rapid fall of $\mathrm{CO}_{2}$ are absolutely necessary to avoid the complications of acidosis. If at the end of the operation, hyperventilation may happen in a normal subject from the respiratory point of view, on the other hand there is the danger of 


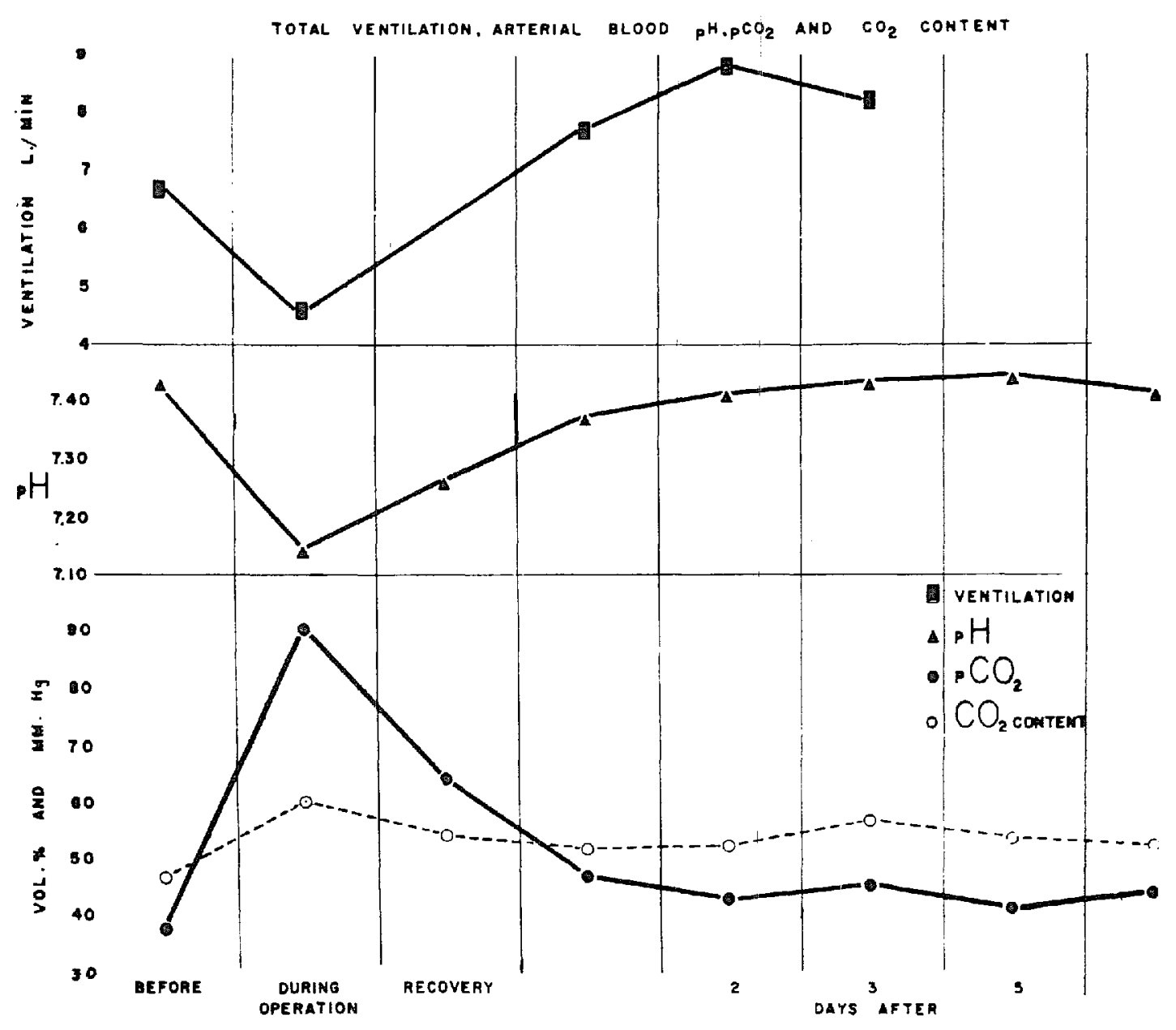

Fig. 11. Total ventilation, arterial blood $\mathrm{pH}, \mathrm{pCO}_{2}$ and $\mathrm{CO}_{2}$ content.

hypoventilation in the emphysematous patient. The patient who does not succeed in maintaining a normal $\mathrm{CO}_{2}$ content, a normal $\mathrm{pCO}_{2}$ and $\mathrm{pO}_{2}$ before operation, may have much more difficulty after it.

The $\mathrm{CO}_{2}$ content and the $\mathrm{pCO}_{2}$ will be increased more, and as soon as the patient starts to breathe room air, he has trouble because of his emphysema. If he has had thoracic surgery he may have paradoxical respiration and very bad ventilation.

These patients cannot get rid of their secretions because of the lack of elasticity and the incapacity to build up enough positive pressure in their lungs. These secretions obstruct the airway and become an impairment to the ventilation. The patient becomes anoxic, the $\mathrm{CO}_{2}$ increases in his blood, the pulmonary artery pressure increases, and there may be failure of the right heart.

If pure oxygen is given, the patient immediately feels better, his minute ventilation diminishes as a result of the saturation of the arterial blood, and i. may happen that the respiration stops because the reflex stimulation of the respiration due to anoxia on the aortic and carotid glomi does not exist any more. More frequently, however, the respiration will continue, but is much diminished; and even if the blood becomes well saturated with pure $\mathrm{O}_{2}$, there is accumulation of $\mathrm{CO}_{2}$, respiratory acidosis, coma, and death. 
How can we prevent this?

The first thing to do is to have a physiological evaluation of the respiratory status of the subjects who have had chronic pulmonary disease prior to anaesthesia.

If the patient is ernphysematous in the third or fourth degree, he should have general anaesthesia only if it is impossible to give him another kind. Then the anesthetist should use a mechanical ventilatory device or control the respiration manually, check the minute ventulation and be sure there is no hypoventilation. A $\mathrm{CO}_{2}$ content and $\mathrm{pH}$ determination are very important and should be done regularly in these patients to prevent increased acidosis.

It is contra-indicated to "ald" the patient's respiration by the continuous inflation of the breathing bag with a slight amount of positive pressure (for example, 3 to $5 \mathrm{~cm}$ of water). Measurements made by Maloney, Derrick, and Whittenberger (13) demonstrated that this continuous positive pressure actually decreased the minute ventilation by 40 per cent on the average. This decrease in ventilation was in addition to the decrease from 8.6 litres to 4.4 that had already occurred when the pleura was entered.

There are several reasons for this effect of continuous inflation:

1. It is mechanically more difficult for the normal lung and still more for the emphysematous one to breathe against the resistance of a distended bag.

2. Continuous pressure causes a reflex slowing of the respiratory rate in many patients.

3. The continuous positive pressure decreases the venous return to the heart, increases the filling time of the heart, and diminishes the stroke volume with a fall in blood pressure if the pressure of $\mathrm{O}_{2}$ is more than $7 \mathrm{~cm}$. of water.

In patients anaesthetrzed in the usual way the finding of tidal volumes which were nadequate to clear the airway dead space was indeed surprising.

Draper, Whitehead, and Spencer (14) have studied diffusion respiration with animals breathing pure $\mathrm{O}_{2}$. They found that the oxygenation remained good, but the $\mathrm{CO}_{2}$ accumu_ated

It seems that this technique is frequently, although unintentionally used, especially during thoracic anaesthesia.

One can easily see how dangerous it is to give 3 to 5 per cent $\mathrm{CO}_{2}$ mixtures to breathe after operation. There is danger of stll further increasing the acidosis except in cases which have been hyperventilated

It seems evident that we know more and more about the possible complications of anaesthesia, but there is still place for research In conclusion, let me quote Dr H. J. V. Morton (15): "Since the earliest days in anaesthesia, respiration has provided helpful signs for those who conduct fellow human beings on journeys through unconsciousness. We have no reason to suspect that the last secret has been revealed, that no more useful information is forthcoming Let us then apply ourselves with renewed vigour to the study of respiration and progress in anaesthesia will surely result."

\section{SUMMARY}

A general review of the nervous and chemical controls of the respiration has been made. 
We have then presented data on ventilation and arterial blood, before, during, and after pulmonary resections in 19 cases, showing that hypoventilation exists and is responsible for the respiratory acidosis that always accompanies the increase in $\mathrm{CO}_{2}$ content and in $\mathrm{PCO}_{2}$.

The effects of $\mathrm{CO}_{2}$ retention on heart and central nervous system during anaesthesia and in the recovery period have been reviewed.

It was sugg,ested that hypoventilation be prevented by means of a ventilatory mechanical cevice or a manual control with a flow meter, maintaining the ventilation at the preanaesthetic level.

It was also suggested that physiolozical tests might be made on subjects who have chronic respiratory disease in orcer to find their respiratory reserves.

\section{RÉSUMÉ}

Une revue générale des contrôles nerveux et chimiques de la respiration a été faite.

Nous avons ensuite présenté les données de la ventilation et du sang artériel avant, durant et après des résections pulmonaires chez 19 individus et avons montré qu'une hypoventilation marquée existe et est la cause d'acidose respiratoire marquée dans certains cas.

Les effets de rétention de $\mathrm{CO}_{2}$ avec chute du $\mathrm{pH}$ sur le cœur et sur le système nerveux central durant l'anesthésie et dans la période de recouvrance ont été analysés.

On a alors suggéré de prévenir l'hypoventilation au moyen d'un appareil mécanique avec pompe, ou à défaut de cet appareil, de contrôler manuellement la respiration à condition de pouvoir en mesurer le débit.

L'importance d'établir le status physiologique respiratoire des patients qui souffrent de maladies pulmonaires chronıques a aussi été indiqué.

\section{REFERENCES}

1 BeEcher, Henry K \& Murphy, ANna J Acidosis duriog Thoracic Surgery. J Thoracic Surg 1950 (1950).

2 Mater, Hereert C., Rich, George W., \& Eichen, Seymour. The Clinical Significance of Respuratory Acıdosis during Operations Am. Surg 134.653 (1951).

3 Miller, F. A, Brown, E B, Buckiley, J J, VAN Bergen, F H. \& Varco, $R$ L Respuratory Acidosis Its Relationship to Cardiac Eunction and Other Physiologic Mechanisms Surgery 32171 (1952)

4 TAYLOR, F. H \& Roos, A. Disturbances in Acid Base Balance during Ether Anesthesia J. Thoracic Surg. 20. 289 (1950).

5. Proctor, D F Respiration and Anesthesia Am Surg 19.812 (1953)

6. Sealy, W. C, Young, W. G, Harris, S Studies on Cardiac Arrest The Relationship of Hypercapnia to Ventricular Fibrilation. J Thoracio Surg. 28: 447 (1954).

7. Maloney, J. V., Derrick, W. S \& Whittenberger, J. J. Device producing Regulated Assisted Respiration. Its Effect on Hypoventilation in Thoracic Surgery, surgical forum. Proceedings of the forum session of the 36th clinical Congress of the American College of Surgeons, Boston, Mass, October, 1950 Philadelphia W. B. Saunders Company (April, 1951), pp. 588-95

8. Goldstern, J D., \& DuBors, E L The Effect on the Curculation in Man of Rebreathing Different Concentrations of Carbon Dioxide. Am J. Physiol 81. 650 (1927).

9 Drupss, R. D. The Immediate Decrease in Blood Pressure seen at the Conclusion of Cyclopropane Anesthesia. "Cyclopropane Shock" Anesthesiology 8. 43 (1947). 
10 Campbeil, Gilbert S Hypercapnia An Abetting Factor un Cardiac Arresi Surgery 33. 915 (1953)

11. Young, W. G., Jr., Sealy, W. C, Harnus, J. \& Botwin, A. The Effects of Hypercapnia and Hypoxia on the Response of the Heart to Vagal Stumulation. Surg., Gynec. \& Obst. 93. 51 (1951).

12. Bnown, E. B., Jr , \& MirIEn, F Ventricular Fibrillation following a Rapid Fall in Alveolar Carbon Dioxide Concentration. Am J. Physiol. 169: 56 (1952).

13 Maloney, J V, Jr, Derrick, W. S. and Whittenberger, J. L. A Device producing, Regulated Assisted Respiration. II. The Prevention of Hypoventilation and Mediastina. Motion during Intrathoracic Surgery Anesthesiology 13. 28 (1952).

14. Draper, W. B., Whitehead, R. W and Spencer, N. Studies on Diffusion Respiration: Alveolar Gases and Venous Blood $\mathrm{pH}$ of Dogs curng Diffusion Respiration. Anesthesiology 8: 524-533 (1947).

15 Monton, H. J V. Respiratory Patterns during Surgical Anaesthesia. Anaesthesia 5: 112 (1950). 